\title{
Middle Easternization of Turkey's Foreign Policy: Does Turkey Dissociate from the West?
}

\section{Tarik Oğuzlu}

To cite this article: Tarik Oğuzlu (2008) Middle Easternization of Turkey's Foreign Policy: Does Turkey Dissociate from the West?, Turkish Studies, 9:1, 3-20, DOI: $10.1080 / 14683840701813960$

To link to this article: https://doi.org/10.1080/14683840701813960

册 Published online: 08 Feb 2008.

Submit your article to this journal ๘

Џll Article views: 2213

Citing articles: 22 View citing articles 5 


\title{
Middle Easternization of Turkey's Foreign Policy: Does Turkey Dissociate from the West?
}

\author{
TARIK OĞUZLU
}

Department of International Relations, Bilkent University, Ankara, Turkey

\begin{abstract}
This essay argues that Turkey's foreign policy has been Middle Easternized. This has mainly been informed by the growing negative impact of political developments in the Middle East_particularly Iraq —on Turkey's feeling of security at home and abroad. Rather than culminating in a breakup with the West, this Middle Easternization process has resulted in the adoption of a more pragmatic/rational than an emotional/romantic approach towards the European Union and the United States. That objections to Turkey's accession to the EU have recently increased despite the start of the accession talks appears to have led Turkish policymakers to adopt a more pragmatic approach towards EU membership. Though the accession talks with the EU have formally started, the end result of Turkey's Europeanization process continues to remain more ambiguous than ever. Though the negative legacy of the March 2003 crisis in US-Turkey relations has been partially repaired, it seems that Turkey and the United States will likely experience growing disagreements over Iraq, the Kurds, Syria, democratization in the Middle East, and Iran in the years to come. The nature of Turkey's future relations with the West will increasingly be determined by what transpires to Turkey's south and east rather than west.
\end{abstract}

\section{Introduction}

This essay argues that Turkey's foreign policy has increasingly been Middle Easternizing. While some interpret this as a calculated action on the part of Turkey to turn the face of the country away from the West towards the East, this essay holds the view that such an outcome has gradually become inevitable, as Turkey's national security interests, as well as the nature of Turkey's relations with the European Union and the United States, have increasingly become informed by developments in the Middle East. In this sense, Middle Easternization does not suggest a break with the West but rather the growing salience of the Middle East in Turkey's relations with the West. The increasing Middle Easternization of Turkey's foreign policy has concomitantly resulted in the adoption of a more pragmatic/rational rather than an emotional/romantic approach towards the EU and the United States.

Correspondence Address: Tarık Oğuzlu, Bilkent University, Department of International Relations, 06800 Bilkent, Ankara, Turkey. Email: oguzlu@bilkent.edu.tr 
Two events have contributed to this outcome. One is the EU's decision to partially suspend accession talks with Turkey. Even though the EU's decision to offer Turkey candidacy status in 1999 and to officially start accession talks in late 2005 brought Turkey closer to the EU, Turkey's approach to the EU has increasingly become "realistic" and "instrumental." Paradoxically, the closer Turkey has come to the EU in an institutional sense, the louder the Turkish people have started to discuss what the EU accession process would entail in terms of their lives and Turkey's national interests. More internal discussions in this regard have taken the romantic and ideational cloud off Turkey's approach to the EU.

Besides, the EU's institutional crisis in the wake of the May 2004 round of enlargement and the rejection of the European Constitution in the national referenda in France and the Netherlands have alerted the Turkish elite to the idea that despite Turkey's increasing Europeanization attempts at home, Turkey's accession to the EU will remain a distant possibility unless the EU resolves its own problems. Though Turkey's eventual accession to the EU would enable the latter to manage its relations and the crises in the Middle East more efficiently, the possibility of the EU offering Turkey strong membership prospects appear to have decreased parallel to the growing chaos and instability in the Middle East. Turkey's immediate membership at this particular time would likely bring the EU much closer to the anarchical Middle Eastern environment. That is why Turkey has sped up its efforts to contribute to the emergence of a stable environment in the region. The stakes are high for Turkey.

Second is the occupation of Iraq by the United States in 2003. Developments since then have demonstrated that Turkey's relations with the United States can no longer continue on the basis of the Cold War-era parameters. Neither the "alliance" type of relations of the Cold War era nor the "strategic partnership" kind of relations of the late 1990s can adequately define the essence of Turkish-American relations. The idea that the United States can be considered as both an ally and a potential security threat has increasingly been heard, as US-led developments have had a tremendous impact on Turkey's national security interests. From now on, the nature of Turkey's relations with the United States will be affected more by developments in the Middle East than Europe.

The process prior to the June 2007 parliamentary elections also appears to have underlined the growing salience of Middle Eastern-related developments on Turkey's national security. Domestic debates during the election campaign revolved around three major issues. One was the question of how to deal with growing Kurdish assertiveness in northern Iraq, whereas another concerned the optimal strategy that Turkey should adopt in dealing with the growing terrorist threat from the Kurdistan Workers Party (PKK). The third issue pertained to the impact of growing feelings of insecurity at home on the nature of Turkey's relations with the United States and the European Union.

The elections of July 22, 2007 once again brought to power the ruling Justice and Development Party (Adalet ve Kalkınma Partisi, AKP), in a landslide. Neither the Republican People's Party (Cumhuriyet Halk Partisi, CHP, the secular nationalists) 
nor the Nationalist Action Party (Milliyetçi Hareket Partisi, MHP, the conservative nationalists) gained enough votes to form a government, either alone or through a coalition. The new parliament also includes members of the Democratic Society Party (Demokratik Toplum Partisi, DTP), the representatives of the ethnic Kurdish nationalists in southeastern Turkey.

Even though the AKP leadership announced that the new government would continue the EU-led liberal democratization process at home and adopt a liberal approach towards the Kurdish question abroad, ${ }^{1}$ the mere fact that both ethnic Kurdish nationalists and secular/conservative Turkish nationalists are represented in parliament makes the solution of Turkey's Kurdish problem and the improvement of Turkey's relations with the Kurds of northern Iraq more urgent than ever.

The risk here is that these two issues have become closely intertwined with Turkey's relations with the West. Given that Turkey finds itself in fundamental disagreement with both the EU and the United States over these issues and that feelings of anti-Americanism and Euroskepticism have been on the rise, the years to come might produce a strange outcome in Turkey's national outlook: that is, Westernization despite the West.

Against such a background, this essay will first discuss the reasons why observers talk about Turkey's dissociation from the West. In this regard, the study will emphasize the challenges leveled against Turkey's Western identity within the context of US-Turkey and EU-Turkey relations. Then, an attempt will be made at demonstrating how the Middle Easternization of Turkey's foreign policy has been underway. Here, the main goal will be to demonstrate the increasing impact of Middle Eastern-related developments on Turkey's security. Turkey no longer feels threatened by Greece or any particular EU policy. Instead, developments in the Middle East in general and in Iraq in particular are becoming more important in the redefinition of Turkey's security interests. Hence, Turkey is adopting a more active and assertive foreign policy approach with a view to helping contribute to the emergence of peace and stability in the Middle East. The strange thing here is that Turkey has gradually transformed into a European country while trying to help resolve security problems in a generally nonEuropean region. Rather than becoming an example of Turkey's dissociation from the West, this demonstrates the extent to which Turkey has adopted the EU's norms in the field of foreign and security policy.

\section{Dissociation from the West}

\section{Identity}

Turkey has increasingly embraced a new strategic thinking in its relations with the West that is based more on cost-benefit calculations than on identity-related factors. This implies two things. One is the realization on the part of Ankara that Turkey's institutional relations with NATO and the EU does not automatically suggest that Turkey is a part of the Western international community and that following a Western-oriented foreign policy always serves Turkey's interest. In line 
with this, Turkish elites have also observed that the "security card" cannot always be considered the most important leverage Turkey has in its relations with the West. Contrary to Turkish expectations, various European circles have put forward some security-related arguments during the post-Cold War era as to why Turkey's accession to the European Union would prove to be problematic. ${ }^{2}$

It was somehow normal to view Turkey as a Western/European country during the Cold War era, when Turkey assisted the West in its efforts to contain and defeat the Soviet threat. ${ }^{3}$ However, when the Cold War came to an end and Turkey's European partners within NATO adopted a Europe-limited strategic outlook, the credentials of Turkey's Western/European identity became diluted.

Turkey has long been denied full membership status within the embryonic European Security and Defense Policy (ESDP) initiative. In addition to the technical requirement that non-EU members cannot be granted such a status in ESDP, there were other serious factors at play. Many European circles, for instance, alleged that Turkey's membership in the European Union would decrease, rather than enhance, European security. Geographically, Turkey is located at the crossroads of unstable regions. Moreover, the strategic horizons of the EU were defined in such a narrow manner that the EU's main occupation in the 1990s was to heel the artificial divisions in Europe and extend the area of the Western European security community to the Central and Eastern European countries. ${ }^{4}$ The Europe-centered strategic outlook of the EU was strengthened further in the post-September 11 era, as the EU has taken utmost care not to get involved in unpopular American polices around the globe. ${ }^{5}$

That the main criterion for membership was defined as meeting the European standards in democratic governance also had a negative impact on Turkey's chance to be included in the EU. Turkey could not meet such standards, mainly because the war against the PKK - the ethnic separatist Kurdish terrorist organization-slowed down the democratic-liberalization process at home. ${ }^{6}$ Moreover, Turkey's membership was considered to have a negative impact on the pace of the EU's deepening integration process, mainly due to the fact that Turkey is simply too big, too poor, and too different. ${ }^{7}$

Despite such developments, Turkish elites have long turned a blind eye to attempts at questioning Turkey's Western/European identity in the West. Turkey even missed the opportunity to realize that the first Gulf War in 1990 helped underline the Middle Eastern aspects of Turkey's identity. ${ }^{8}$

Ankara also could not read the transformation of NATO in the post-Cold War era correctly. As NATO started to transform from a Europe-centered collective defense organization into a non-Europe-oriented semi-military/semi-political collective security organization, Ankara's idea that its membership in NATO would continue to legitimize its Western/European identity became questionable. ${ }^{9}$ As NATO has turned out to be a "tool box" for the United States in its global war on transnational terrorism, the European identity of the Alliance has further been diluted. ${ }^{10}$

Second, Turkish elites have increasingly become aware of the fact that the pronunciation of the Eastern aspects of Turkey's national identity, namely, Turkey's 
Islamic character and the legacy of the Ottoman Empire, might accrue her more benefits than costs in her relations with the West. This is not to suggest, as some observers tend to argue, that Turkey has begun to turn its face away from the West towards the East but rather that there is a strategic calculation that such a course of action will simply increase Turkey's bargaining power vis-à-vis the West. The old equation that "the more Turkey renounces its Eastern identity, the more chances it will have in the confirmation of its Western identity" has been replaced by a more pragmatic equation in that "the acceptance of Turkey's placement in the West will be more likely through the strengthening of Turkey's links to the East." Turkey is increasingly capitalizing on its Eastern identity with a view to securing its place within the West. ${ }^{11}$

\section{The United States}

The geographical distance between the two countries and the strategic cooperation against common external threats remained obstacles for Turkey regarding the adoption of a more pragmatic approach towards the United States for a long time. Despite the evaporation of the good old days during the Cold War era, Ankara long believed that bilateral relations between the two would remain untouched by the dissolution of the Soviet Union. ${ }^{12}$ While Turkey expected full American support for its vital interests, the United States expected Turkey, the junior party in this relationship, to unconditionally comply with American policies in Turkey's environment. Turkey initially expected that the events of September 11 would help increase Turkey's value in Washington, for the United States would increasingly need the cooperation of an ally such as Turkey in the global war on terror. However, the US invasion of Iraq in 2003 simply dashed such expectations. ${ }^{13}$

Turkey long failed to understand that the end of the Cold War and the speeding up of the globalization process would fundamentally transform the nature of its relations with the United States. Turkey should have grasped much earlier that the changing balance of power between the United States and other systemic actors in favor of the former would result in more unilateral, aggressive, and militaristic American foreign policies around Turkey. ${ }^{14}$ The increasing power of the United States has negatively affected the countries that had traditionally been considered "allies" since the outset of the Cold War era.

From the early 1990s until the 2003 occupation of Iraq, the attitude of the United States towards Turkey also delayed Turkey's efforts to come to grips with changing realities. For instance, successive Washington administrations unconditionally supported Turkey's membership in the EU; made it clear that stability in Turkey was more important than its liberal democratic transformation; adopted a more balanced approach towards the Cyprus dispute in comparison to the pro-Greek attitude of the European Union; helped Turkey in its struggle against the PKK, even playing a key role in the apprehension of the PKK leader; defined Turkey as a model country for the Westernization attempts of the countries in Turkey's environment; and last but not least considered Turkey as a partner in the global strategic competition in the 
Caucasus and Caspian regions. ${ }^{15}$ However, the point here is that such US backing of Turkish policies emanated from the convergent interests between the parties concerned. The United States approached Turkey from a pragmatic point of view.

A case study in this regard is Turkey's relations with the United States over Iraq. Ankara long believed that the United States' acquiescence in Turkey's concerns vis-à-vis Iraq during much of the 1990s was an example of the Cold War-era alliance relationship. In fact, cooperation with the United States became possible within the context of Washington's double containment policy towards Iran and Iraq. Turkey was the main US ally in the region necessary for the sanctions regime on Saddam's Iraq to succeed. Turkey made use of this in its efforts to militarily intervene in northern Iraq to chase after PKK terrorists. ${ }^{16}$ Turkey's cooperation with the West in northern Iraq within the framework of Operation Provide Comfort/ Operation Northern Watch does not, however, suggest that Turkey's Western allies, particularly the European members, always acquiesced to Turkey's way of dealing with PKK terrorism and the Iraqi Kurds.

However, immediately after the 2003 invasion of Iraq, Turkey started to see that its interests do not always converge with those of the United States. The latter is Turkey's neighbor to the south and sees the Iraqi Kurds as an ally in the region. Despite the fact that in September 2006 Turkey and the United States established an institutional mechanism to coordinate their efforts on the PKK-the appointment of special representatives on terror-and that the parties signed a formal document in 2006 regulating the modalities of their strategic cooperation, there has been no serious contribution to the evaporation of the crisis atmosphere in bilateral relations. Reflecting this reality, anti-Americanism in Turkey is on the rise, given that a majority of the Turkish people think that the United States does not adequately support Turkey's struggle with the PKK and that Washington's policies towards Iran and Syria have a negative impact on Turkey's chances of improving relations with these countries. ${ }^{17}$

The United States opposes Turkey's military operations against PKK terrorists based in northern Iraq, mainly because Iraqi Kurds strongly object to such a possibility and because any Turkish military incursion might lead to a military clash between the Kurds and Turkey. Besides, the United States appears to support the Kurdish claim on Kirkuk that the final status of the city should be determined by a referendum to be held in December 2007, as article 140 of the Iraqi Constitution stipulates. Given that US soldiers are increasingly preoccupied by a growing insurgency and the ongoing civil war in Iraq, the emergence of a war in northern Iraq is one of the last things that Washington would like to see.

Northern Iraq is not the only area where Turkey and the United States diverge from each other. Turkey considers the attitude of the United States towards Iran and Syria as a potential threat to its security. ${ }^{18}$ Turkey would certainly benefit from the democratization of its neighbors. However, if such democratization came through external pressure and the use of brute force, Turkey fears that it would produce more chaos and anarchy than stability. Turkey also shares a common security concern with its neighbors to the south, in that the rising influence of Kurdish nationalism in 
the region is against their interests. They all fear the negative consequences of such a development on their domestic stability, for all are home to substantial Kurdish minorities.

Excluding Iran and Syria - the members of the so-called axis of evil-from any peace process in the Middle East is not a realistic course of action from Ankara's perspective. Ankara strongly believes that the United States should certainly engage these countries through a diplomatic process if she wants to see that they soon transform into stable and democratic countries. ${ }^{19}$ For Ankara, the only way to bring regime change in Iran and Syria is to open the channels of communication with the leadership in these countries. The more these regimes are encouraged to integrate into the globalized world, the more they will face domestic pressure in favor of democratization and liberalization. That said, Ankara hopes that the US efforts to engage Iraq's neighbors through diplomatic channels, as recommended by the Iraq Study Group Report of December 2006, help improve domestic security in Iraq.

It is worth mentioning in this regard that despite Iran's increasing geopolitical power, the country does not appear to be an existential security threat for Turkey. First, the two countries have not fought each other for a long time, and the territorial border between the two has remained the same since the early seventeenth century. Second, Turkey's security policymakers do not buy into the argument that Iran is close to developing nuclear weapons. Turkey holds the views that Iranian attempts to get nuclear energy are driven mainly by economic needs; that Iran feels encircled by the US presence in Afghanistan and Iraq; and that Iran is threatened by Israel's nuclear power. To Ankara, the Iranian desire to acquire nuclear weapons is better explained by the concerns of gaining international prestige and the ability to deter adversaries rather than the concern of changing the status quo in the region in a revisionist fashion. ${ }^{20}$

What concerns Ankara, however, is that Iran's acquisition of nuclear weapons as a result of escalating tension with the United States would be against Turkey's interest. Ankara would likely be exposed to growing American calls to worsen its relations with Iran as part of US-led international efforts to squeeze the regime in Tehran, and the need to invest in nuclear armament would be felt more deeply in the Turkish capital. In fact, Turkey has already been in the process of planning its own nuclear program. The risk here is that if Turkey's attempts at acquiring peaceful nuclear energy were interpreted as the early stages of Turkey's efforts to become a nuclear-armed regional power, the prospects of Turkey's EU membership might decrease. $^{21}$

The negative reaction of the American government to the July 2007 deal between Turkey and Iran concerning the transportation of Iranian and Turkmen gas through Turkey to European markets is also noteworthy in this regard. Because Turkey is in dire need of alternative energy resources and thinks that transmitting Iranian gas to Europe will improve its relations with the European Union, bowing to US pressure that Turkey should cease investing in the Iranian economy at an amount of more than 20 million dollars does not strike a sympathetic chord across the political spectrum in Ankara. It is interesting that the EU is also supportive of Turkey's gas 
cooperation with Iran. ${ }^{22}$ Once again, Turkey has found itself squeezed between the United States and its neighbors in the Middle East, this time Iran.

\section{The EU and the Accession Process}

Turkey has for decades looked at the EU from a mix of emotional and ideational points of view. Because membership in the EU has been conceptualized as the latest stage of Turkey's march to modernity and contemporary civilization, relations with the EU gained a psychological character. ${ }^{23}$ On a platform where rational cost-benefit calculations were missing, even the slightest successes in the EU accession process were considered victories, while temporary crises were looked upon as defeats. One can, for example, look to the comments made by the majority of the Turkish elites in the aftermath of the signing of the Customs Union Agreement to see traces of such a mentality. Nearly the whole Turkish political spectrum interpreted Turkey's Customs Union with the EU as the harbinger of Turkey's full membership within the next decade. ${ }^{24}$

The same mentality appeared again in the wake of the infamous Luxembourg Summit of the EU in December 1997, where Turkey was not even included among the second group of countries to which the EU would expand in the next enlargement round. Right after the summit, Turkey simply cut off political dialogue with the EU to demonstrate her disillusionment. Turkey's exclusion from the next enlargement process led to the rise of pessimism and a mix of nationalistic and cultural arguments that the EU discriminated against Turkey on the basis of inherent differences. ${ }^{25}$

In the past, neither the situation that would eventually take place following full membership nor the dynamics of the accession process were considered from a rational/instrumental point of view. The transformative effects of member status and the logic of the complex accession criteria were not given sufficient consideration in Ankara. The EU was mainly considered as an intergovernmental organization focused mainly on economic issues. The hope was that the EU would eventually let Turkey in because of US support for Turkey's application and the strategic security role that Turkey played during Cold War era would help convince the EU of the appropriateness of Turkey's accession. ${ }^{26}$

Set against this background, the changes in Turkey's approach towards the EU since December 1999, when the EU recognized Turkey's candidacy status, should be interpreted with great importance. A growing number of Turkish elites argue that the EU enlargement strategy itself has a rational logic, according to which the countries that meet membership criteria and are easy to "digest" are accepted for membership, whereas the countries that are likely to slow down the EU integration process and are difficult to "absorb" are simply kept waiting until appropriate conditions arise. ${ }^{27}$

In comparison with the past, the current debate in Turkey is important for the simple reason that it helps accelerate the formation of rational approaches towards the EU. Important proof of this rationality is that many Turks see clear differences 
between EU membership itself and the accession negotiations that would theoretically pave the way for this. The latter is now considered more important than the former, for its effects on the makeup of Turkish society are more observable in the short to medium term.

It would be appropriate here to mention the ongoing domestic debate on this matter. For example, both pro-EU and Euroskeptic Turkish circles appear to agree on the point that Turkey's future should lie in Europe. However, they simply disagree on how to interpret the EU's intentions in this regard. ${ }^{28}$ Skeptics question the terms of the accession process and consider Turkey's struggle to meet the Copenhagen criteria as an act against the well-established Kemalist security understanding. ${ }^{29}$ Moreover, these people argue that even if Turkey met all the membership criteria, that country might not even join the club, for membership would depend on the approval of every single EU member, among which France, Austria, Cyprus, and Greece would likely say "no." They also note that the principle of "absorption capacity" would likely make Turkey's EU membership a distant possibility. These circles are also concerned by the possibility that if Turkey were not let in after radical liberalization and democratization processes, Turkey's internal peace would be negatively affected. This process could even lead to Turkey's dismemberment.

On the other hand, the circles that support Turkey's membership and the steps taken to this end believe above all that such efforts serve Turkey's own interest rather than anybody else's. ${ }^{30}$ These circles simply think that the length of the process is normal because the EU has to prepare itself for Turkey's membership as much as Turkey needs to. They also believe that if Turkey fulfills the Copenhagen criteria, the EU will have no choice but to accept Turkey as a member; otherwise, the EU would be contradicting its own security identity and the principles of the integration process.

Reflecting the rise of the rational approach towards the European Union, Ankara has begun to capitalize on its links to the Middle East more than ever. This is in line with Ahmet Davutoğlu's argument that the EU should no longer be seen as the institution to confirm Turkey's Western/European identity, the well-known ideational point of view, but rather as an instrument contributing to Turkey's global power. ${ }^{31}$

Such instrumentality/pragmatism can also be diagnosed in the way that Turkey tries to market its EU membership. The old argument that Turkey was vital for the European continent's security simply does not hold true in today's world. The EU's enlargement processes in the 1990s have already helped stabilize Europe. With the accession of Romania and Bulgaria in January 2007, and other countries in southeastern Europe and the Balkans by 2012, the EU will have eventually resolved the major security questions on the continent.

The current Turkish government is well aware of this fact. This is why Ankara has been trying to increase its chances of membership by pointing out Turkey's potential contributions to the EU's security in the context of the Middle Eastern and Eurasian regions. The arguments put forward in this regard are simply as follows: Turkey is becoming an energy corridor. If Europe wants to have secure access to energy sources in the Caspian region and in Central Asia, mainly oil and natural gas, 
it needs to cooperate with Turkey. Turkey offers the only feasible route for Europe to lessen its dependence on Russian energy sources. ${ }^{32}$

Second, Turkey is vital for the EU's attempts at successfully dealing with the problems of illegal trade in humans and drugs. Third, Turkey's membership would also endow the EU with the legitimacy that it needs in its efforts to enhance its international standing in the greater Middle East. The EU's reaching out to the region would be much easier with the membership of a predominantly Muslim country such as Turkey. Turkey's membership would also help the EU deal with Europe's Euro-Muslim community, who make up at least five percent of Europe's population. ${ }^{33}$ Turkey's accession to the European Union would help the Europeanization of Islam both in Turkey and in the EU itself. Turkey offers one of the rare examples of the cohabitation of Islam and secular democracy. If Europe wants to evolve into a multicultural entity with secular norms defining the contours of its identity, Turkey's membership would prove to be critical.

Fourth, Turkish authorities are increasingly arguing that if the EU wants to have an effective international role in line with its emerging European Security and Defense Policy, Turkey's membership would help a great deal. Turkey has a strong army experienced in peacekeeping and peacemaking activities. Fifth, Turkey is trying to prove that it is vital for the preservation of European security interests in the Eastern Mediterranean region. In this framework, the attitude adopted by Turkey towards the solution of the Cyprus dispute and the steps taken to improve TurkishGreek relations result from a growing Turkish desire to convince skeptical Europeans about the contributions that Turkey could make to regional security.

Turkey's adoption of a more pragmatic approach towards the European Union can also be seen in the way in which the AKP government has reacted to the EU's decision to partially suspend the negotiation process in late 2006. Rather than reacting emotionally, as the coalition government of Mesut Yilmaz did back in 1997, the AKP government made it clear that Turkey would nevertheless continue the reformation process to prevent the EU from finding an additional excuse to further delay Turkey's eventual accession. The government seems to have also understood that the EU's internal problems are making it difficult for EU politicians to easily convince the Turkey-skeptical European public opinion of the appropriateness of Turkey's membership. Therefore, a short cooling-off period might help both parties develop new strategies to deal with the deadlock.

Despite such developments, some other events, mostly emanating from the EU, have caused a rising disillusionment with the EU on the part of Turkey. Not only the Euroskeptic ulusalc ${ }^{34}$ opposition but also the pro-EU AKP government has felt disappointed by the EU's stance on the Cyprus issue. Ankara has seen that the EU simply reneged on its promise to reward the Turkish Cypriots for their cooperative stance on the Annan Plan. Instead, the EU admitted the Greek Cypriot Administration as a member representing the whole island and let the deadlock on the island impair the continuation of Turkey's accession talks.

Other developments that seem to have fueled Turkey's growing disenchantment with the EU are the open-ended nature of Turkey's accession talks; the attempts at 
linking Turkey's eventual membership to the EU's absorption capacity; the growing calls inside the EU to offer Turkey a privileged membership, as proposed by the German government or a seat in the Mediterranean Union, as proposed by French President Nicolas Sarkozy; the emerging consensus that Turkey's membership should be voted on in a national referendum; the emerging view that if Turkey wants to join the European Union, it needs to recognize the so-called Armenian genocide; and so forth.

Another disappointment in this regard has emerged as the EU's approach towards Turkey in the post-September 11 era has been increasingly shaped by the "logic of identity" rather than the "logic of interests" or the logic of "cosmopolitan rights." The more the Europeans have began to see Islam as an existential threat in the post-September 11 era, the more they tend to define Turkey as one of the potential "others" of the EU's emerging identity. Similarly, Pope Benedict XVI asked European leaders to refer to Christianity in the proposed European constitution as one of the mainstays of European civilization. In such a context, the ones who are traditionally in favor of Turkey's accession would find it difficult to explain why Turkey's membership would be in the economic and security interests of the EU as well as a legitimate course of action within the framework of the EU's cosmopolitan principles.

\section{Orientation toward the Middle East}

\section{The Rise of Islam as Turkey's Identity?}

The Middle Easternization of Turkey's foreign policy might also be attributed to the rise of cultural and historical factors. In fact, this process dates back to the early years of the post-Cold War era. Following the dissolution of the Soviet Union, Turkey tried to develop closer economic and political relations with the newly established states in Central Asia, the Caucasus, and the Balkans. In doing this, the Turkic and Islamic aspects of Turkey's identity were considered by many as crucial assets.

However, expectations in this regard were not met by Turkey's capabilities. Besides, aspirations to join the European Union became the most important foreign policy interest. In the past, Turkey long considered itself a natural part of the Western international community and chose to view regional developments from a Western point of view. It was within such a context that the majority of Turkish elites believed that the less the Islamic and Eastern characteristics of Turkish identity were emphasized, the more the secular and Western aspects of Turkish identity would be realized, hence increasing prospects of joining the EU. ${ }^{35}$

Unlike previous Turkish governments, the AKP government has been putting more emphasis on Turkey's Islamic and Middle Eastern characteristics. ${ }^{36}$ One of the motivating factors in this regard is the commonly held belief that Turkey, as the inheritor of the Ottoman Empire, holds a particular responsibility for the nature of international relations in this region. ${ }^{37}$ The AKP government behaves as such not only to increase 
the country's leverage vis-à-vis the West but also to help allay Turkey's security concerns emanating from this region. For example, forging relations with Iraq's Sunni groups on the basis of religious affinity was considered a legitimate course of action in this regard. It is in line with such thinking that Turkey did its best to convince Iraqi Sunni groups to take part in the elections held in $2005 .^{38}$

The rise of Islam in Turkish foreign policy can also be seen through Turkey's closer engagement with Hamas, the political party that came to power in the Palestinian territories in the elections held there in early 2006. Emboldened by Hamas's Islamist character, the AKP government has asked it to recognize Israel as soon as possible, put an end to terrorist attacks, seek a solution based on the idea of two independent states in the region, and honor the previously signed agreements between Israel and the Palestinian Authority. ${ }^{39} \mathrm{~A}$ similar logic can also be detected behind Turkey's increasing efforts to tell Iran that the latter should act in cooperation with the international community regarding the dispute over Iranian nuclear policies. ${ }^{40}$

It is also of great importance that AKP figures have continuously counseled the leaders and people of Islamic countries to give priority to democratization, liberalization, and development. The institutional platforms of the Organization of the Islamic Conference and the Organization of the Arabic Union provided Turkish statesmen with such opportunities. ${ }^{41}$ The fact that a Turkish national was elected as secretary general of the Organization of Islamic Conference can also be mentioned here as demonstrating the rise of Islam in Turkey's approach towards the Middle East.

It is noteworthy that while taking such critical steps, the AKP government has taken utmost care to not be seen as acting as the spokesperson of the West in the region, for the main reason that the West's unwavering support of Israel and the USled wars in Afghanistan and Iraq have contributed to the erosion of United States' power of attraction in the Islamic world. ${ }^{42}$ It seems that the AKP government has also increasingly referred to Turkey's Islamic identity in an instrumental way to attract as much Arabic capital as possible.

\section{Threat Perceptions from the Middle East}

Another factor driving the Middle Easternization of Turkey's foreign policy is that Turkey's security interests have been growing since September 11 due to developments in this region.

Turkey has for a very long time felt threatened by the developments resulting from its relationship with the European Union despite the fact that the EU has been the main international institution Turkey has wanted to join. The love-hate relationship with the EU, the ambiguous European approach towards Turkey's membership application, the legacy of the Sèvres Treaty, Greece's instrumental use of its EU membership against Turkey, and increasing European demands that Turkey needs to democratize and liberalize have all aggravated Turkey's security concerns. ${ }^{43}$

However, the reforms carried out in the framework of the EU membership process and the start of the accession talks have changed Turkey's security perceptions 
vis-à-vis the EU. Besides, Greece is now among the EU members that have overtly supported Turkey's accession to the Union as well as the resolution of the Cyprus dispute within the framework of the so-called Annan Plan. Reflecting this positive mood, the National Security Policy Document that was approved by the government in late 2005 does not mention Greece as one of the existential threats Turkey faces. ${ }^{44}$ Similarly, the percentage of Turkish citizens that consider the EU to be a threat does not go beyond five percent, as some public opinion polls have revealed. ${ }^{45}$

This is so despite the fact that Turkey's relations with the West are not free of crises and that the EU, in December 2006, suspended accession talks with Turkey over eight chapters of the whole negotiation package due to Turkey's objection to opening its airports and seaport to Greek Cypriot aircrafts and ships as part of its requirements emanating from its Customs Union with the EU. ${ }^{46}$

The main threats Turkey now faces seem to emanate from the chaos in Iraq, the increase in the regional influence of Iran, the democratization strategies implemented by the United States in the greater Middle East, and the increasing linkage between external and internal developments.

What happens in northern Iraq clearly will have an impact on Turkey's security at home. Growing exposure to Middle Eastern developments helps weaken Turkey's ability to adopt the EU's security understanding. The pace and nature of Turkey's liberal democratic reformation process at home, a precondition for Turkey's accession to the European Union, is closely intertwined with Turkey's security perceptions vis-à-vis northern Iraq. The rise of Kurdish nationalism, alongside the growing possibility of Iraq's dismemberment, militates against the solution of Turkey's own Kurdish problem through liberal democratic openings, a requirement for EU membership. The more Turkey feels itself threatened by the rise of Kurdish nationalism in the Middle East, the more difficult it will be to solve the Kurdish problem through the process of politicization. In contrast to the expectations of the European Union, politicization of Kurdish problem has not led to its desecuritization. For Turkey to successfully proceed with the EU-related reformation process at home, what needs to exist is a stable and cooperative regional security environment in the Middle East. Otherwise, Turkey will likely estrange itself from the EU's security model, in which threats to states' territorial integrity and sovereignty no longer exist and are increasingly being defined in reference to individuals and societies.

Given this, Turkey's recent efforts to become proactive in the Middle East and to play a kind of facilitating role in the resolution of the crisis between Iran and the US-led Western international community are quite understandable. Turkey simply tries to help transform the Middle East, lest the developments there affect its domestic stability. To pursue such a foreign policy in the region is the most important security strategy that Turkey currently employs.

\section{Acting as a European Country in the Middle East}

Ankara has also become aware of the possibility that Turkey's proximity to the growing chaos and instability in the Middle East might have contributed to the EU's 
reluctance to accept Turkey for membership. Therefore, Ankara has intensified her efforts to help to bring into existence a cooperative and stable environment in the Middle East. Doing this would both help to produce a conducive environment for the continuation of liberal democratic reforms at home and assure EU circles that Turkey is in fact a security-producing country.

Reflecting this reality, Turkey has employed the EU's security strategies while trying to help transform the Middle East in its own image.$^{47}$ Increasing economic cooperation with the countries in the region, making its own state-society model attractive for them, and making them believe that cooperation with Turkey would also serve their own security are the main components of Turkey's regional security strategy in this regard. Turkey is acting as a European country in the Middle East, just as Greece is seen as a European country in the Balkans, rather than a Balkan country in Europe. That the accession process with the EU just started has increased Turkey's power of attraction in the region, and Turkish authorities are well aware of this. They simply capitalize on this. ${ }^{48}$

Another sign of this growing European identity in foreign policy is the fact that elected politicians are becoming more influential in the formation of Turkish foreign policy choices than appointed military and civilian bureaucrats. ${ }^{49}$ Even in northern Iraq and Cyprus, the two issues on which the primacy of the appointed security bureaucrats has long been deemed legitimate, the government has succeeded in softening Turkey's approaches and bringing them more in line with the positions of the European Union. That is why, for example, the AKP government has not easily bowed to the growing domestic pressure that the Turkish army should enter northern Iraq in order to eliminate PKK terrorism. This shows that in terms of process there is a trend toward Europeanization in Turkish foreign policy. The same can also be said of the style of Turkish foreign policy. Turkey speaks more softly, multilaterally, and cooperatively than ever. In terms of outcomes/ outputs, the result is somehow mixed. When issues of concern do not touch upon Turkey's vital security interests, Turkey tends to ally with the European Union, such as on the Israeli-Palestinian dispute, democratization in the Middle East, and energy cooperation.

Even on vital security issues, one can observe greater Europeanization. A growing number of Turkish elites advocate a political solution to the Kurdish problem. The radical reforms that the AKP government has made contributed to this process. For example, though exposed to strict time limitations, the state-run TRT channel broadcasts programs in the Kurdish language. However, one must acknowledge that private channels are not allowed to broadcast programs in Kurdish, nor is the Kurdish language taught in regular state schools. Some taboos on the use of Kurdish in education still persist, mainly owing to security concerns. The prime minister has clearly emphasized that Turkey has a Kurdish problem, rather than a PKK-related terrorism problem, and that Turkey must find a solution to this problem through further democratization and liberalization. ${ }^{50}$ The strange thing here is that Turkey has been taking such steps while developments in northern Iraq have affected Turkey's security interests, almost negatively. 


\section{Conclusion}

Based on the analysis above, the main conclusion of this essay is that Turkey's approach towards the West is now more pragmatic than ideational. Relations with the United States and the EU are important as far as they help Turkey deal with the challenges of the globalization process rather than confirm Turkey's Western identity, and that Turkey would certainly increase its leverage vis-à-vis the West if it capitalized on the Eastern and Islamic aspects of its national identity. However, this does not suggest that Turkey dissociates from the West. Instead, acting as a European country in the non-European Middle East testifies to the Europeanization of Turkey's foreign policy.

The crucial thing here is that Turkey's cooperation with the West in the years to come will likely depend more on the attitudes of the West towards Turkey than on other factors. First, the West should sincerely support the ongoing liberal democratization process at home. In this regard, the American response to the involvement of the Turkish military in politics has not been promising. Rather than taking a clear preference in favor civilian political forces, Washington adopted a neutral approach when the Turkish general staff put an e-warning on its official website on April 27, 2007, implying that the army would do all that it could to stem the tide of desecularization.

Second, the Western world should be cognizant of the fact that the true guardians of Turkey's Western-oriented secular identity are the majority of the Turkish people, not the army. That substantial numbers of the Turkish people organized street demonstrations in different parts of the country prior to the July 2007 parliamentary elections in order to demonstrate their preference for a secular lifestyle is a promising sign in this regard. Similarly, the fact that the AKP has truly become a centrist party, getting votes from different segments of the Turkish people, is encouraging.

Third, the West should immediately grasp the reality that the overwhelming majority of the Turkish people share a strong disillusionment with the West. ${ }^{51}$ The emerging view is that the EU's reluctant approach towards Turkey's membership and the United States' increasing criticisms of Turkey's way of dealing with PKK terrorism and Iraqi Kurds have had a negative impact on Turkey's security interests. Under such conditions, the AKP government, despite all its pro-EU inclinations, might find it difficult to justify the ongoing Europeanization process in the eyes of the public, for all political parties in parliament adopt more nationalistic and Western-skeptic discourses than the AKP does. They all seem sympathetic towards a military strike against PKK bases in northern Iraq and a more hawkish stance regarding the status of Kirkuk in Iraq. They also tend to interpret Turkey's efforts to meet the EU accession criteria as concessions given to the major European powers. It is not a secret that even some retired members of the Turkish army have argued for Turkey's withdrawal from NATO and for forging a strategic cooperation with Russia, Iran, and China. ${ }^{52}$

Lastly, the policymakers in Washington and Brussels should see that the goal of EU membership has proven to be the most important incentive bringing Turkey's 
secular elites and the AKP government together in functional cooperation. The continuation of the accession process with the EU has been the main reason why the secular forces in Turkey have somehow tolerated the AKP's allegedly political Islamist past. That said, should the prospects of Turkey's accession to the EU decrease in the years to come, particularly due to internal EU factors, the AKP's continuous efforts in meeting the EU's liberal democratic standards might increasingly be considered by the secular elites as threatening the mainstays of Turkey's Kemalist security understanding. The fear that Turkey's Europeanization might result in its Islamization might come true. Worse than this, Turkey's further disengagement from the West might intensify its fear of growing Kurdish assertiveness in the Middle East and lead her to adopt a more hawkish approach towards northern Iraq.

\section{Notes}

1. What is meant by the liberal approach towards the Kurdish question abroad is that Turkey both adopts an integrationist approach towards northern Iraq and views Iraqi Kurds as Turkey's relatives as opposed to potential enemies. The goal is to integrate this particular region into Turkey through extensive economic and social engagement.

2. For example, see Barry Buzan and Thomas Diez, "The European Union and Turkey," Survival, Vol.41, No.1 (1999), pp.41-57.

3. Gülnur Aybet and Meltem Müftüler-Baç, "Transformations in Security and Identity after the Cold War: Turkey's Problematic Relationship with Europe,” International Journal (2000), pp.567-82.

4. Martin A. Smith and Grahem Timmins, "The EU, NATO, and the Extension of Institutional Order in Europe," World Affairs, Vol.163, No.2 (2000), pp.80-90.

5. Despite the fact that the EU members have been militarily involved in Afhghanistan and Lebanon and increased their efforts to mediate the conflict with Iran over the latter's nuclear policies, this does not override the reality that such EU policies were informed more by the desire of not being marginalized in the post-September 11 era, particularly in the eyes of Washington, than the existence of convergent European and American foreign and security policy priorities. See Richard Whitman, "No and After: Options for Europe," International Affairs, Vol.81, No.4 (2005), pp.673-87.

6. Ersel Aydinlı and Don Waxman, "A Dream Become Nightmare? Turkey's Entry into the European Union," Current History, Vol.100, No.649 (2001), pp.381-9; Fotios Moustakis and Rudra Chaudhuri, "Turkish-Kurdish Relations and the European Union: An Unprecedented Shift in the Kemalist Paradigm?" Mediterranean Quarterly, Vol.16, No.4 (2005), pp.77-89.

7. Ole Waever, "Identity, Integration and Security," Journal of International Affairs, Vol.48, No.2 (1995), pp.389-432.

8. Rather than coming to terms with such a reality, Turkish elites have long preferred to believe that Turkey's increasing security role in the Middle East would help increase its value in the West and eventually pave the way for its accession to the EU. For example, see Daniel Pipes, "Turkey's Relations with the West and the Turkic Republics: The Rise and Fall of the 'Turkish Model,'" Middle East Quarterly, Vol.8, No.3 (2001), pp.92-5; Ziya Öniş, "Turkey in the Post-Cold War Era: In search of Identity," Middle East Journal, Vol.49, No.1 (2005), pp.48-68.

9. Mahmut Bali Aykan, "Turkey and European Security and Defense Identity/Policy (ESDI/P): A Turkish View," Journal of Contemporary European Studies, Vol.13, No.3 (2005), pp.335-59.

10. The US-led war on global terror has demonstrated this point clearly.

11. Ahmet Davutoğlu, Stratejik Derinlik Türkiye'nin Uluslararası Konumu [Strategic Depth: Turkey's International Location] (Istanbul: Küre Yayınları, 2001), pp.323-454.

12. Ekavi Athanassopoulou, "American-Turkish Relations since the End of the Cold War," Middle East Policy, Vol.8, No.3 (2001), pp.144-64. 
13. James Kapsis, "From Desert Storm to Metal Storm: How Iraq Has Spoiled US-Turkish Relations," Current History, Vol.104, No.685 (2005), pp.380-9.

14. Scott A. Cooper, "Air Power and the Coercive Use of Force," Washington Quarterly, Vol.24, No.4 (2001), pp.81-93; and Barry M. Blechman and Tamara Cofman Wittes, "Defining Moment: The Threat and Use of Force in American Foreign Policy," Political Science Quarterly, Vol.114, No.1 (1999), pp.1-30.

15. Athanassapoulou (2001).

16. Bill Park, "Turkey's Policy towards Northern Iraq: Problems and Perspectives," in Adelphi Paper (London: International Institute of Strategic Studies, 2005), p.374.

17. Steven A. Cook and Sherwood Randall, "Generating Momentum for a New Era in U.S.-Turkey Relations," Council on Foreign Relations Press, June 2006, available at http://www.cfr.org/content/ publications/attachments/TurkeyCSR.pdf.

18. Ibid.

19. For a detailed view of Turkish Prime Minister Erdoğan on democratization in the Middle East, see: http://turkishweekly.net/articles.php?id=7.

20. Tarik H. Oğuzlu, "Soft Power in Turkish Foreign Policy," Australian Journal of International Affairs, Vol.61 (2007), pp.81-97.

21. Sami Kohen, "Belgeyle Biter mi?" Milliyet, April 27, 2006, available at http://www.milliyet.com/ 2006/04/27/yazar/kohen.html.

22. For example, the energy minister of the British government points out that Turkish-Iranian gas cooperation will also boost the EU's Nabuco Project. See: http://www.worldpoliticsreview.com/article. aspx?id=1220.

23. Ziya Öniş, "An Awkward Partnership: Turkey's Relations with the European Union in ComparativeHistorical Perspective," Journal of European Integration History, Vol.7, No.1 (2001), pp.105-19.

24. Atilla Eralp, "Turkey and the European Union in the Post-Cold War Era," in Alan Makovsky and Sabri Sayarı (eds.), Turkey's New World Changing Dynamics in Turkish Foreign Policy (Washington, DC: Washington Institute for Near East Policy, 2000), pp.173-88.

25. Ziya Öniş, "Turkey, Europe and Paradoxes of Identity: Perspectives on the International Context of Democratization," Mediterranean Quarterly, Vol.10, No.3 (1999), pp.107-36.

26. Meltem Müftüler-Baç, "Turkey's Role in the EU's Security and Foreign Policies," Security Dialogue, Vol.31, No.4 (2000), pp.489-502.

27. Lauren M. McLaren, "Turkey's Eventual Membership of the EU: Turkish Elite Perspectives on the Issue," Journal of Common Market Studies, Vol.38, No.1 (2001), pp.117-29.

28. Ziya Öniş, "Domestic Politics, International Norms, and Challenges to the State: Turkey-EU Relations in the Post-Helsinkli Era," Turkish Studies, Vol.4, No.1 (2003), pp.9-34.

29. Suat İlhan, Avrupa Birliği'ne Neden Hayır Jeopolitik Yaklaşım [Why No to European Union Geopolitical Approach] (Istanbul: Ötüken Yayınları, 2000); Suat İlhan, Avrupa Birliği'ne Neden Hayir 2 [Why No to European Union 2] (Istanbul: Ötüken Yayınları, 2002); and Ümit Özdağ, Türkiye Avrupa Birliği Illişkilerini Jeopolitik Inceleme [The Geopolitical Analysis of Turkey-EU Relations] (Ankara: ASAM Yayınları, 2002).

30. Ersel Aydinlı and Ali Resul Usul, "Looking towards Europe," World Today, Vol.58, No.10 (2002), pp.10-12.

31. Davutoğlu (2001), pp.517-47.

32. Tayyip Erdoğan, "Our European Destiny," Global Agenda (14790289), Vol.4, No.1 (2006). See also Sevgi Drorian, "Rethinking European Security: The Inter-regional Dimension and the Turkish Nexus," European Security, Vol.14, No.4 (2005), pp.421-41.

33. Ayhan Kaya and Ferkat Kentel, Euro-Türkler Türkiye Ille Avruğa Birliği Arasinda Köprü mü, Engel $m i$ ? [Euro-Turks: Are They the Bridge between Turkey and the European Union or Obstacles?] (Istanbul: Bilgi Üniversitesi Yayınlar1, 2005). See also Nilüfer Göle, "Europe's Encounter with Islam: What Future?" Constellations: An International Journal of Critical \& Democratic Theory, Vol.13, No.2 (2006), pp.248-62.

34. "Ulusalc1" does not refer to a specific group of people acting in an ordered and institutionalized manner. The term is rather an adjective that denotes the people across the county who are sensitive about the 
mainstays of Turkey's Kemalist security identity, namely, the preservation of Turkey's secular, homogenous, and unitary state identity. These people are not principally against the idea of Turkey's membership in the European Union. Instead, they would like to see that Turkey becomes a member of the modern international community as represented by the European Union. What they are against is the possibility of the erosion of the foundational logic of the Turkish Republic with the Europeanization process. The active and retired members of the Turkish military and state bureaucracy are included within this configuration.

35. Mustafa Aydin, "The Determinants of Turkish Foreign Policy and Turkey's European Vocation," Review of International Affairs, Vol.3, No.2 (2003), pp.306-31.

36. Michael M. Gunter and Hakan Yavuz, "Turkish Paradox: Progressive Islamists and Reactionary Secularists," Critique: Critical Middle Eastern Studies, Vol.16, No.3 (2007), pp.289-301.

37. Bülent Aras, "The Turks and Jerusalem," Contemporary Review, Vol.279, No.1629 (2001), pp.201-8.

38. Mehmet Demirkaya, "Türkiye, ABD'lilerle Sünnileri Buluşturdu," available at http://www.milliyet. com/2005/12/05/siyaset/siy01.html.

39. http://www.sabah.com.tr/2006/02/26/siy98.html.

40. For example, Abdullah Gül, Turkey's foreign minister, visited Iran and counseled the Iranian authorities that Iran should give serious consideration to the proposal of the international community on the issue of Iran's nuclear goals. See http://www.samanyoluhaber.com/tr/Dunya/a.16043.html.

41. http://www.cnnturk.com/HABER/haber_detay.asp?PID=319\&HID=1\&haberID=191314 .

42. Meliha Altunışık, "The Turkish Model and Democratization in the Middle East," Arab Studies Quarterly, Vol.27, No.1/2 (2005), pp.5-63; Adel Safty, "The Middle East and the West: Historical Representation as a Dimension of Political Relation," Arab Studies Quarterly, Vol.17, No.1/2 (1995), pp.136-47; and Pew Research Center's research on global images of US power, available at http://pewglobal.org/reports/pdf/252.pdf.

43. Hasan Kosebalaban, "Turkey's EU Membership: A Clash of Security Cultures," Middle East Policy, Vol.9, No.2 (2002), pp.130-46.

44. http://www.milliyet.com/2005/05/13/guncel/gun06.html.

45. Cüneyt Ülsever, “ABD'ye Açık Uyarı Yeni Siyaset Belgesi Tamam” [Open Warning to the USA, the New Policy Document is Ready], Hürriyet, April 9, 2006, ABD'ye Açık Uyarı, available at http:/ /www.radikal.com.tr/haber.php?haberno=167981.

46. "AB'yle Kıbrıs Restleşmesi” [Challenging the EU over Cyprus], available at http://www.radikal. com.tr/haber.php?haberno=190414.

47. Michael Emerson and Nathalie Tocci, "Turkey as a Bridgehead and Spearhead Integrating EU and Turkish Foreign Policy,” EU-Turkey Working Papers No.1 (Center for European Political Studies, 2004).

48. Zeynep Daği, “Orta Doğu Perspectifinden Türkiye'nin Avrupa Entegrasyonu: Ötekileşme Aşilıyor mu?" [Turkey's Integration to Europe from the Middle Eastern Perspective: Transcending the Process (or Practice) of Othering (or Otherization)], Demokrasi Platformu [Democracy Platform], Vol.1, No.4 (2005), pp.97-113.

49. Ali L. Karaosmanoğlu, "The Evolution of Turkey's Security Culture," Journal of International Affairs, Vol.54, No.1 (2000), pp.199-217.

50. Ayşe Betül Çelik and Bahar Rumelili, "Necessary But Not Sufficient: The Role of the EU in Resolving Turkey's Kurdish Question and the Greek-Turkish Conflicts," European Foreign Affairs Review, Vol.11, No.2 (2006), pp.203-22.

51. For example, one can read the latest report of the Pew Global Research on Turkish attitudes towards the West. See http://pewglobal.org/reports/pdf/256.pdf. This poll was released in June 2007.

52. For example, see the following comments: http://www.todayszaman.com/tz-web/yazarDetay.do? haberno $=114626$. 